\title{
Analysis of Pisa 2012 Participant Countries' Success Rankings in Terms of Their Patent Productivities
}

\section{Duygu İleritürk}

Ataturk University, Kazım Karabekir Education Faculty, Educational Sciences Department, duygu.birbiri@atauni.edu.tr

\section{Remzi Y. Kıncal}

Prof., Ataturk University, Kazım Karabekir Education Faculty, Educational Sciences Department, rkincal@atauni.edu.tr

It was thought in this study that it was important to analyze the countries' economic situation and patent production based on their information transfers via their success rankings in PISA, which determined their success internationally. Therefore, it was aimed to analyze the countries' success in participation into the PISA 2012. Case study design, one of the types of qualitative research, was used in the study. Document analysis was used for data collection instrument and data analysis. The countries in the study were analyzed according to PISA success rankings, patent application numbers, registered patents and gross national products. The study findings stated that patent application averages were parallel with their PISA success rankings for some countries like China, Turkey etc. Moreover, while the countries with the highest gross national product averages had parallel patent production, it was seen that the countries like Indonesia with high gross national product were not at similar levels in terms of both patent production and success rankings in PISA because of its population. According to the study results, it was suggested that Turkey's and other countries' patent circulations could be analyzed until 2012 comparatively, and the relationship between patent production and research-development works should be investigated.

Keywords: PISA, patent production, creativity, education, innovation

\section{INTRODUCTION}

When many scientific and technological changes have brought out, the educational, technological or scientific outputs of the countries have stood out with their usages and creativities in the current age. According to the changing current conditions, technological developments, productivity and competition are seen as the basements of the countries' economies. So, each country tries to succeed the products which enables them stand out at international level. Nowadays, knowledge-driven or competitive 
business environment is considered as innovation in the societies. Innovation refers to the process of bringing valuable new products to the market i.e. from the idea/concept formulation stage to the successful launching of a new or improved product in the market place, or the result of that process, to meet the explicit or implied needs of current or potential customers (Kalanje, 2017). Especially economists have made significant progress in growth modelling and understanding of the mechanisms of economic growth over the past five decades. So, it also appears that economists have reached a consensus on the notion that long-run economic growth is primarily a product of technical or technological innovation (Tebaldi and Elmslie, 2013).

Creative discoveries or products are made out via intellectual or mental efforts, and also they are called as intellectual quality (Al Kassiri and Corejova, 2015). The information, which has occurred as an intellectual quality in knowledge based society, is defined as transferrable and practicable human capital after research and development process. While a knowledge or idea has been researching and gaining intellectual quality in patent process, it affects the economy positively (Baskaya at al., 2015). The most important factor for succeeding at societal, economic and technological levels which the countries aim in the speed and interaction network that information technologies have created, and in the cultural environment that the concepts of quality and competition have changed, is the sustainability of discoveries and innovations according to knowledge based economies. While innovations are concerned with the commercialization of new ideas; in contrast, an 'invention' may not be directly associated with commercialization. As such, innovation may be seen as a process of interaction and feedback during the various stages of the new product development process. An invention is considered as the generation of a new idea or knowledge, which aims to solve a specific technical problem. Inventions could relate to products or processes and are characteristically protected by trade secrets, utility models/petty patents or patents. Utility models/petty patents or patents are granted/registered under the relevant national/regional law by the relevant national or regional patent office. As not all inventions are commercialized, so it is clear that not all inventions result in innovations (Kalanje, 2017). The significance of education and learning has come out due to technological innovations and discoveries depending on creativity. Improving creativity depends on development of intellectual capital in the information age (Kavak, 2009). Patents are the main parts for sustainability of technological developments and knowledge interactions in the current age. The patented discoveries have gained an innovative feature and also they could be used as financial gain within the developing production (Baskaya, Klumpp and Cuypers, 2015). Patents are considered to be a comprehensive resource for characterizing inventions and generating appropriate patent indicators (Khramova at al., 2013). The number of patents owned by an enterprise has often been used as one of the main indicators for determining innovation intensity of that enterprise. In addition, patents are also used as a measure of output of innovation (Kalanje, 2017). Patents are the direct products of technological researches, and also the product could support to increase academic productions and to contribute to them financially (Baskaya at al., 2015). Therefore, education has an important role for enabling sustainability of development as institutionally and developing the institutions. 
Patents are significant predictors for growth rather educational institutions (Bjornskov and Meon, 2013). In this manner, it could be said that the actions and services of educational institutions contribute to the production of patents and growth indirectly. The competitive market in the international manner also supports to increase and to develop the practices and products of the countries in their education systems while increasing skilled labor via education contributes to economy (Hoareau at al., 2013). Skilled labor and economy contribute to each other alternately, and so it could also be pointed out to increase the quality of education and its practices. Sims (2013) states that measuring the effectiveness of a country's educational system can be difficult because of the fact that it is too difficult to compare the countries especially internationally. Therefore, some researchers have used international tests instead of national standardized tests or grade. The effect upon education of growing economies of the countries is determined partially according to the international tests' results and rankings which are the determiners of educational success of the countries internationally (Parcero and Ryan, 2016). So, the success rankings of PISA and TIMSS, which are organized to identify the countries' academic success internationally, could be said to be related to the patent production based on information transfer and economic structure indirectly. The relationship between patents and economic growth arises out of the rationale that stronger patent rights positively influence innovation through cost-saving technologies and new product development, which in turn promote economic growth (Hudson \& Minea 2013; Raghupathi \& Raghupathi, 2017). Innovation and economic growth have supported each other bidirectionally(Pradhan at al., 2018). It is also related to the investment at national and global level. It could be said that investing education is a very significant determiner for innovation and economic growth (Kourtit at al., 2018). So, the international tests enable the researchers to analyze both the academic and cognitive skills of the countries partially, and also they contribute to the relationship between economic growth and education of the countries. Moreover the countries' population is also an identifier for economic growth because of the fact that there are so many positive and negative evidences about their relationship. Furuoka (2018) has stated that the theory proposes under a condition when negative effects of population growth on per capita income dominate the relationship between the two variables, population growth has a detrimental effect on economic growth. Zhang's study (2015) has been implemented to examine the relationship between population and economic growth in ten Asian countries for the period of 1991-2012. The findings were mixed: the relationship between population and economic growth was negative in five countries while in the other five countries the relationship was positive. Moreover, GarzaRodriguez et al. (2016) employed different methods to examine the relationship between population growth and economic growth in Mexico for the period of 1960-2015. The researchers discovered bidirectional causality between population and economic growth in the country. Therefore, in this study the success rankings of the countries, which participated into PISA 2012, would be aimed to be analyzed in terms of their patent productivities and gross national products. Accordingly, research question has been organized as follows. 
'How does the success rankings of the participant countries into PISA 2012 change according to their patent applications, registered patents, populations and gross national products?'

\section{METHOD}

\section{Research Design}

Qualitative research method was used in the study. Qualitative case study design was used as the research design. Researchers in the case study don't follow a stable form like the article in the other research designs. Qualitative case studies are the research types in which one or more cases are analyzed in a deep way (Yin, 2014). Many data collection instruments such as interview, focus group interview, observation or document analysis could be used in case studies. Case study is not a specific technique, but so it is that the data are brought out together to point the utility of the social object (Punch, 2014). The study was limited to PISA 2012 success rankings and 2012 patent and population data.

\section{Data Collection and Analysis}

Document analysis was used for data analysis in the study. Document analysis is an analysis of materials which include information about the research question. The documents used in the study could be written materials (book, magazine, newspaper, letter, diary, formal forms or statistics) and also film, video or photographs related to the issue. The importance of the sources and which of them is used as data source are related to the research topic and questions (Merriam and Tisdell, 2016). The data of the study were collected from World Bank reports, the statistics and formal reports published by World Intellectual Property Organization (WIPO) and OECD reports. So, the study was limited to the reports and statistics about 2012 and PISA 2012 average success rankings. Rowlinson (2004) stated five different stages of classification which was done for document analysis. Rowlinson has started firstly to obtain and organize the documents used in the study. After the first stage is done, the other stages are as follows, respectively: checking the originality by testing documents' reliabilities and validities, understanding the documents, analyzing the documents by classifying them within a category or categories, and using them in the study report. In the study, the following steps were followed in the analysis of the documents.

1. Obtaining and organizing the documents: What kinds of documents were needed and how they were reached were identified in terms of research question and aims. So, WIPO and OECD reports and statistics including PISA 2012 and patent applications, registered patents and gross national products were reached.

2. Checking originality: The data used in the study were the primary data, and they were obtained from the formal websites and publications.

3. Understanding the documents: PISA 2012 success rankings and WIPO statistics about patents were analyzed comparatively.

4. Analyzing the documents: Data set included all the document and they were analyzed into seven categories according to the research aim. These categories were prospectively the average scores of mathematical literacy of PISA 2012, average scores of science literacy of PISA 2012, the average scores of reading skills literacy 
of PISA 2012, population, patent applications, registered patents in 2012 and gross national products relating to 2012. Data consistency was done by two different experts. The data relating to each country's average scores were analyzed according to the variables, and so the data obtained from data analysis were classified into the categories. Each category was evaluated by two researchers.

5. Using the documents in the study: The analyzed data were interpreted in the findings and results of the study.

\section{FINDINGS}

\section{The analysis of success rankings of the participant countries in PISA 2012}

Table 1

The averages, population, patent applications, registered patents and gross national products of the countries above OECD average in PISA 2012 (OECD, 2013; WIPO, 2016)

\begin{tabular}{|c|c|c|c|c|c|c|c|}
\hline & $\begin{array}{l}\text { Average points } \\
\text { of mathematical } \\
\text { literacy of PISA } \\
2012\end{array}$ & $\begin{array}{l}\text { Average } \\
\text { points of } \\
\text { reading } \\
\text { literacy of } \\
\text { PISA } 2012 \\
\end{array}$ & $\begin{array}{l}\text { Average } \\
\text { points of } \\
\text { science } \\
\text { literacy of } \\
\text { PISA } 2012 \\
\end{array}$ & $\begin{array}{l}\text { Population } \\
\text { (million) }\end{array}$ & $\begin{array}{l}\text { Patent } \\
\text { applications in } \\
2012\end{array}$ & $\begin{array}{l}\text { Registered } \\
\text { patents in } \\
2012\end{array}$ & $\begin{array}{l}\text { Gross } \\
\text { National } \\
\text { Product } \\
\text { (\$ billion) }\end{array}$ \\
\hline OECD average & 494 & 496 & 501 & & & & \\
\hline Shanghai-China & 613 & 570 & 580 & & & & \\
\hline Singapore & 573 & 542 & 551 & 5.47 & 13.488 & 7498 & 401.78 \\
\hline $\begin{array}{l}\text { Hong Kong - } \\
\text { China }\end{array}$ & 561 & 545 & 555 & & & & \\
\hline Taiwan-China & 560 & 523 & 523 & & & & \\
\hline China & & & & 1364.27 & 678.872 & 225.394 & 14880.59 \\
\hline South Korea & 554 & 536 & 538 & 50.42 & 244.615 & 141.517 & 1595.20 \\
\hline Macao-China & 538 & 509 & 521 & & & & \\
\hline Japan & 536 & 538 & 547 & 127.13 & 546.054 & 393.399 & 4463.07 \\
\hline Liechtenstein & 535 & 516 & 525 & 0.04 & 1026 & 542 & - \\
\hline Switzerland & 531 & 509 & 515 & 8.19 & 43.523 & 19.795 & 436.41 \\
\hline Netherlands & 523 & 511 & 522 & 16.85 & 31.643 & 16370 & 619.62 \\
\hline Estonia & 521 & 516 & 541 & 1.31 & 296 & 201 & 32.75 \\
\hline Finland & 519 & 524 & 545 & 5.46 & 13.069 & 6.493 & 213.79 \\
\hline Canada & 518 & 523 & 525 & 35.54 & 57.361 & 31409 & 1454.99 \\
\hline Poland & 518 & 523 & 526 & 38 & 6290 & 2829 & 865.56 \\
\hline Belgium & 515 & 509 & 505 & 11.23 & 12.263 & 6420 & 362.78 \\
\hline Germany & 514 & 508 & 524 & 80.89 & 197.768 & 80.245 & 3453.99 \\
\hline Vietnam & 511 & 508 & 528 & 90.73 & 3849 & 1072 & 436.08 \\
\hline Austria & 506 & 490 & 506 & 8.53 & 12.692 & 5661 & 372.74 \\
\hline Australia & 504 & 512 & 521 & 23.49 & 35.450 & 96.644 & 22.172 \\
\hline Ireland & 501 & 523 & 522 & 4.61 & 4341 & 2096 & 204.91 \\
\hline Slovenia & 501 & 481 & 514 & 2.06 & 496 & 232 & 56.95 \\
\hline Denmark & 500 & 496 & 498 & 5.64 & 11.179 & 4537 & 239.70 \\
\hline New Zealand & 500 & 512 & 516 & 4.51 & 8568 & 6913 & 144.61 \\
\hline Czech Republic & 499 & 493 & 508 & 10.51 & 2036 & 1153 & 297.80 \\
\hline
\end{tabular}

In total, 65 countries participated in PISA 2012 with OECD countries and other countries which are not members of OECD. PISA 2012 consists of science, reading skills and mathematical literacy sub-fields. According to Table 1, when the averages of the countries have been analyzed, Shanghai-China, Singapore, Hong Kong-China, Taiwan-China and South Korea have stood out to be top 5. Moreover, patent applications and registered patents have been held wholly for China but Hong Kong, 
Shanghai and Taiwan in China participated in PISA 2012. So, there is no data for these provinces individually.

Table 2

The averages, population, patent applications, registered patents and gross national products of the countries at OECD average in PISA 2012 (OECD, 2013; WIPO, 2016)

\begin{tabular}{|c|c|c|c|c|c|c|c|}
\hline & $\begin{array}{l}\text { Average points } \\
\text { of mathematical } \\
\text { literacy of PISA } \\
2012\end{array}$ & $\begin{array}{l}\text { Average } \\
\text { points of } \\
\text { reading } \\
\text { literacy of } \\
\text { PISA } \\
2012 \\
\end{array}$ & $\begin{array}{l}\text { Average } \\
\text { points of } \\
\text { science } \\
\text { literacy of } \\
\text { PISA } \\
2012 \\
\end{array}$ & $\begin{array}{l}\text { Population } \\
\text { (million) }\end{array}$ & $\begin{array}{l}\text { Patent } \\
\text { applications } \\
\text { in } 2012\end{array}$ & $\begin{array}{l}\text { Registered } \\
\text { patents in } \\
2012\end{array}$ & $\begin{array}{l}\text { Gross } \\
\text { National } \\
\text { Product } \\
\text { ( } \$ \text { billion) }\end{array}$ \\
\hline France & 495 & 505 & 499 & 66.2 & 72.077 & 41.825 & 2443.39 \\
\hline $\begin{array}{l}\text { United } \\
\text { Kingdom }\end{array}$ & 494 & 499 & 514 & 64.51 & 59.427 & 24.146 & 2327.31 \\
\hline Iceland & 493 & 483 & 478 & 0.33 & 327 & 154 & 12.80 \\
\hline Latvia & 491 & 489 & 502 & 1.99 & 371 & 262 & 41.90 \\
\hline Luxemburg & 490 & 488 & 491 & 0.56 & 2501 & 1152 & 35.50 \\
\hline Norway & 489 & 504 & 495 & 5.14 & 6525 & 3359 & 319.28 \\
\hline Portugal & 487 & 488 & 489 & 10.4 & 1154 & 315 & 272.89 \\
\hline Italy & 485 & 490 & 494 & 61.34 & 29394 & 16558 & 2072.74 \\
\hline Spain & 484 & 488 & 496 & 46.4 & 12053 & 5449 & 1495.37 \\
\hline $\begin{array}{l}\text { Russian } \\
\text { Federation }\end{array}$ & 482 & 475 & 486 & 143.82 & 49889 & 34799 & 3336.48 \\
\hline Slovakia & 482 & 463 & 471 & 5.42 & 403 & 231 & 137.48 \\
\hline USA & 481 & 498 & 497 & 318.86 & 747.522 & 361.245 & 15878.11 \\
\hline Lithuania & 479 & 477 & 496 & 2.93 & 211 & 113 & 70.84 \\
\hline Sweden & 478 & 483 & 485 & 9.69 & 18.873 & 12.309 & 411.84 \\
\hline Hungary & 477 & 488 & 494 & 9.86 & 1721 & 990 & 221.28 \\
\hline Croatia & 471 & 485 & 491 & 4.24 & 377 & 244 & 86.13 \\
\hline
\end{tabular}

Table 2 shows that France, United Kingdom, Iceland, Latvia, Luxemburg, Norway, Portugal, Italy, Spain, Russian Federation, Slovakia, USA, Lithuania, Sweden, Hungary and Croatia have been at OECD average. 
Table 3

The averages, population, patent applications, registered patents and gross national products of the countries below OECD average in PISA 2012 (OECD, 2013; WIPO, 2016)

\begin{tabular}{|c|c|c|c|c|c|c|c|}
\hline & $\begin{array}{l}\text { Average } \\
\text { points of } \\
\text { mathematical } \\
\text { literacy of } \\
\text { PISA } 2012\end{array}$ & $\begin{array}{l}\text { Average } \\
\text { points of } \\
\text { reading } \\
\text { literacy } \\
\text { of PISA } \\
2012 \\
\end{array}$ & $\begin{array}{l}\text { Average } \\
\text { points of } \\
\text { science } \\
\text { literacy } \\
\text { of PISA } \\
2012 \\
\end{array}$ & $\begin{array}{l}\text { Population } \\
\text { (million) }\end{array}$ & $\begin{array}{l}\text { Patent } \\
\text { applications in } \\
2012\end{array}$ & $\begin{array}{l}\text { Registered } \\
\text { patents in } \\
2012\end{array}$ & $\begin{array}{l}\text { Gross } \\
\text { National } \\
\text { Product } \\
\text { (\$ } \\
\text { billion) }\end{array}$ \\
\hline Israel & 466 & 486 & 470 & 8.22 & 17857 & 7515 & 241.41 \\
\hline Greece & 453 & 477 & 467 & 10.96 & 1135 & 517 & 277.22 \\
\hline Serbia & 449 & 446 & 445 & 7.13 & 266 & 183 & 90.02 \\
\hline Turkey & 448 & 475 & 463 & 75.84 & 6215 & 1453 & 1336.18 \\
\hline Romania & 445 & 438 & 439 & 19.91 & 1299 & 452 & 351.06 \\
\hline Cyprus & 440 & 449 & 438 & 1.15 & 447 & 151 & 27.40 \\
\hline Bulgaria & 439 & 436 & 438 & 7.23 & 385 & 143 & 112.82 \\
\hline $\begin{array}{l}\text { United Arab } \\
\text { Emirates }\end{array}$ & 434 & 442 & 448 & 9.45 & 1603 & 90 & 524.98 \\
\hline Kazakhstan & 432 & 393 & 425 & 17.29 & 504 & 139 & 361.11 \\
\hline Thailand & 427 & 441 & 444 & 67.22 & 7005 & 1095 & 907.35 \\
\hline Chile & 423 & 441 & 445 & 17.77 & 3467 & 893 & 367.63 \\
\hline Malesia & 421 & 398 & 420 & 30.19 & 7811 & 2825 & 640.95 \\
\hline Mexico & 413 & 424 & 415 & 123.8 & 16.239 & 12.738 & 1972.25 \\
\hline Montenegro & 410 & 422 & 410 & 0.62 & 79 & - & 8.51 \\
\hline Uruguay & 409 & 411 & 416 & 3.42 & 730 & 41 & 62.63 \\
\hline Costa Rica & 407 & 441 & 429 & 4.94 & 645 & 74 & 63.25 \\
\hline Albania & 394 & 394 & 397 & 2.89 & 1 & 0 & 28.46 \\
\hline Brazil & 391 & 410 & 405 & 202.03 & 32.240 & 3491 & 3026.27 \\
\hline Argentina & 388 & 396 & 406 & 41.8 & 5157 & 1078 & - \\
\hline Tunisia & 388 & 404 & 398 & 11 & 666 & 624 & 114.34 \\
\hline Jordan & 386 & 399 & 409 & 6.61 & 466 & 60 & 71.65 \\
\hline Colombia & 376 & 403 & 399 & 48.93 & 2196 & 1714 & 555.09 \\
\hline Qatar & 376 & 388 & 384 & 2.27 & 129 & 10 & 268.60 \\
\hline Indonesia & 375 & 396 & 382 & 252.81 & 76 & 19 & 2303.46 \\
\hline Peru & 368 & 384 & 373 & 30.77 & 1207 & 436 & 327.24 \\
\hline
\end{tabular}

According to table 3, Israel, Greece, Serbia and Turkey's scores are much more parallel with OECD averages while Albania, Brazil, Argentina, Tunisia, Jordan, Colombia, Qatar, Indonesia and Peru's scores are much lower than OECD averages. Table 3 shows that the rates of the registered patents to patent applications of Jordan (\%12), Costa Rica (\%11) and Uruguay (\%5) are the lowest.

\section{Analyzing the participant countries in PISA 2012 in terms of population}

When the participant countries' population has been analyzed, the most populated countries are respectively China-1364.27 million, USA- 318.86 million, Indonesia-252 million, Russian Federation - 143 million and Japan-127 million. Montenegro (620.000), Luxembourg (560.000), Iceland (330.000) and Liechtenstein (40.000) have been found to be the least populated countries. It could be said that Turkey, which has 75.84 million, has been one of the most populated countries. China and Japan, which are highly most populated countries, could be said to draw attention to their education systems because they are also top performers in PISA 2012. 


\section{Analyzing the participant countries in PISA 2012 in terms of patent applications}

While patent production had \%9.2 growth in 2012, it could be seen that the growth rate has been the fastest in the last 18 years (World Intellectual Property Organization, 2013). According to the participant countries` success rankings in PISA 2012, USA 747.522, China - 678.872, Japan - 546.054, South Korea - 244.615, Germany197.768, France-72.077, United Kingdom-59.427, Canada-57.361, Russian Federation49.889 and Switzerland-43.523 patent applications has been done, and so they are seen to be top 10. According to 2012 patent data, Albania-1, Indonesia-76, Montenegro-79, Qatar-129, Lithuania - 211, Serbia- 266, Estonia-296, Iceland-327, Latvia-371, Croatia377 and Bulgaria-385 patent applications have been the lowest performers at patent applications. Turkey's patent applications were 6215 in 2012. Patent application averages show the countries' productivity, so it could be said to be a significant indicator in determining the relationship among productivity, creativity and academic PISA success.

\section{Analyzing the participant countries in PISA 2012 in terms of registered patents}

According to the registered patent numbers in 2012, the top countries have been Japan393.399, USA-361.245, and South Korea-141.517. China-225.394 has been the country with one of the most registered patents but it has not been included in the study because of the fact that it participated in the PISA regionally. The countries with low performers at registered patent numbers have been Montenegro and Albania-0, Qatar-10, Indonesia19, Uruguay- 41, Jordan- 60 and Costa Rica-74. When analyzed the correlation between the countries, patent applications and registered patent numbers, the rates of the registered patents to patent applications are Croatia \%64, Lithuania \%53, Iceland \%40, Bulgari \%38, Latvia \%70 and Serbia \%68 while Croatia, Lithuania, Iceland, Bulgaria, Latvia and Serbia have the least patent applications. There have been no registered patents for Montenegro and Albania which had the least registered patents. Moreover Japan, which was one of the most patent applications in 2012, has had $\% 72$ registered patents to patent applications while the rate of registered patents of USA, which had the most patent applicants in 2012, has been $\% 48$ to its patent applications. China has had $\% 33$ registered patents to patent applications while South Korea has had \%57 registered patents to patent applications. Therefore, the rates between the countries' patent applications and registered patents could be said to be related to their levels of development. According to the rates between registered patents and patent applications, it could be said that Japan is the top performer at registered patents.

Table 3 shows that according to the rates of registered patents to patent applications, Jordan (\%12), Costa Rica (\%11) and Uruguay (\%5) are the lowest. According to the patent data of 2012, Turkey's patent applications were 6215 while registered patents of Turkey were 1453. The rate between registered patents and patent applications of Turkey is \%23. USA has had the most gross national product with $\$ 16.163 .158 .000$ while China has been the second one with $\$ 8.461 .623 .162 .714$ according to the data of gross national product of the countries of 2012. So, it could be said that the countries' gross national products are parallel with their patent applications and registered patents. According to table 3 , Indonesia has a high value for gross national product - 
\$917.869.913.365 but its patent applications and registered patents are not parallel with each other because of its population growth. The countries, whose gross national products have lower than the other countries, are Montenegro (\$56.485.301.967), Iceland (\$14.194.519.025), Estonia (\$23.135.266.649), Luxembourg (\$55.986.712.368) and Latvia (\$28.023.276.372). Their population sizes could be said to be parallel in terms of their gross national products. According to Turkey's gross national product of 2012 , it was $\$ 778.863 .301 .670$. Moreover, Turkey's gross national product could be seen to be similar to Canada's gross national product which is one of the most developed countries, but they are not parallel with each other in terms of patent applications.

\section{CONCLUSION AND DISCUSSION}

The countries' development levels and their production are parallel with each other. Both of them have affected themselves alternately. It brings out innovation, so innovation has a long developmental process. There are so many identifiers of innovation and patent is one of these identifiers (Wen at al., 2017). Therefore, patents are the most important element in showing the countries' development levels and their productivities. Patents make the countries be more internationalized (Picci \& Savorelli, 2018). International efforts in teaching, learning and assessment of collaborative and creative problem solving skills in recent years clear empirical insights that present the relationship among the countries' creativity and productivity (Tan at al, 2018). The international tests results like PISA could be a determiner of the countries' development levels to some extent. PISA is to assess not only the participant countries' academic levels but also their productivities, problem solving skills and creativities. Moreover, it is seen as a significant indicator for determining the participant countries' levels and their productivity based on the academic knowledge. Academic science and especially industrial innovation have a deep linkage between them. It could be an indicator for improving their innovations quality (Zahringer at al., 2017). According to the findings of the related studies, knowledge recombination with the productivity has caused important understandable innovation productivity (Zahringer at al., 2017; Woo \& Choi, 2018). Therefore, it could be said that there would be a significant relationship between knowledge and productivity, and so patent productivities of the participant countries in PISA 2012 have been analyzed according to their success rankings in PISA 2012 in the study.

The participant countries in PISA 2012 have been analyzed in terms of their gross national products, patent productions and registered patents, and they have been compared with their PISA success. However, it enables the countries to determine their location globally, especially top performers in PISA 2012 in similar to their patent production, which is an indicator of creativity and innovation. While one of the aims of PISA is to make an open and competitive market, it has been seen for educators that the participant countries' results are an indicator for economic competition for the future via evaluating students' cognitive skills (Sjoberg, 2016; Zhao, 2016). Patent production, which enables the countries to be at higher ranking in the competitive economy, is parallel with determining their future capacities, which is one of the PISA aims 
(Sjoberg, 2016). The related studies show that creativity and knowledge production have a strong relationship between them (Autant-Bernard et al., 2017; Drivas et al., 2018; Picci \& Savorelli, 2018). Accordingly, the countries with high performances in the international success rankings could be expected to be at higher levels in terms of creativity, entrepreneurship and patent production statistics.

In this manner, China, Japan and South Korea -top performers in PISA- have been found out to be at higher levels in terms of patent applications and registered patents according to the findings of the study. Therefore, it has been seen that USA, Germany, France, United Kingdom, Switzerland and Canada have also been at higher rankings in patent applications. The countries' policy consistencies on technological competitiveness have had highly crucial impacts on their patent productivities. Therefore, these countries have had higher policy consistencies to secure their sustainable technological competitiveness (Yoon at al., 2017). Patent applications could be said to be a significant predictor for the countries' development levels. Shanghai, Singapore, Hong Kong, Taiwan and South Korea have been identified as educational stars and for other countries who would like to improve their educational performance (Deng \& Gopinathan, 2016). According to the study findings, the more developed countries intellectually have been come out to be parallel with each other in terms of patent applications. Al and Taskin (2015) have stated that increasing information value has achieved its contribution aim, which enables the economy via transforming theory into production. Therefore, transforming information into the production as a raw material could be said to be a significant indicator about both the countries' economic and intellectual development levels.

The other important result of the study is the rate between the patent applications and the registered patents. When the registered patents of China, USA, South Korea and Japan, which are top performers at patent applications, have been analyzed, USA has the most registered patents, and also its rate of registered patents has been $\% 48$. It is pointed out that while the rate of China's registered patents is \%33, the rate of Korea's registered patents is $\% 47$. It has been outstandingly understood that the rate of Japan's registered patents is $\% 72$ although it has been in the higher rankings in PISA 2012. Another important result is that the rates of registered patents of Croatia, Latvia and Serbia are as \%64, \%70 and \%68 respectively though they are the countries with the lowest rate for patent application. So, registered patents are an important indicator as well as patent applications to determine countries' development levels. Dang \& Motohashi (2015) have stated in their study that patent applications and registered patents have strong correlation with $R \& D$ (research \& development) expenditures. Patent application procedures are more accessible for the countries than registration because of the fact that each country has a unique patent registration process and use societal intellectual knowledge (Byun at al., 2018; Robinson \& Raven, 2017; Srivastava, 2017). R\&D studies have important roles to register patents and transfer intellectual knowledge into the production. So, it could be said that patent applications and R\&D studies would be handled with together to increase the registered patents.

Research results state that China and USA are at the first rankings in terms of gross national product and population size. Population intensities of China and USA are 
different from each other, but they are the top countries in PISA 2012 in terms of population. In this manner, it could be said that the population sizes, gross national products and patent applications of China and USA have been parallel with each other. Moreover, there is a negative relationship between especially Indonesia's population and gross national products notwithstanding that Indonesia and Brazil are the most crowded countries. Indonesia has the lowest rate for patent production contrary to income and population. Knowledge based patent production is seen to be an important element for developed and innovatory product creation (Federico \& De La Vega, 2010). Therefore, it is thought that Indonesia PISA success being at lower rankings is a predictor of enabling product development; in other words it is the predictor of transforming theory into practice. However, the Indonesian population and yearly income for a person should be taken into consideration. So it is seen to be highly low for Indonesian people. Current competitive environment, especially in developed countries, and technical qualifications enhanced their practice fields, and also laboratory environments in which different practices are implemented would enable to increase innovatory approaches (Henri at al., 2015).

Accordingly, any professions and professional skills especially in Indonesia, a developing country, are significant elements for determining the countries' economic performances (Florida \& Mellander, 2010). According to table 3, the differences among the lower ranking countries have reflected their transformation learning into ability, so it has reflected their productivity. So it could be said that their low performances in PISA 2012 may be an indicator for their low patent productivities (Gneezy at al., 2017). So, it could be said that patents are important indicators transforming human capital into technological innovation and innovatory performance. Indonesia is both one of the most crowded country in terms of population and also has the biggest economy in Southeast Asia (TMMOB, 2007). Therefore, human capital, called as educated ones and created qualified labor, could be said to cause the countries to fall behind because of inadequate employment and insufficient environments for transforming qualified human capitals into technological developments and innovations especially in developed countries. Moreover $\mathrm{Hu}$ et al. (2017) state that patents are driven by technology innovation by estimating patent production function and increasing labor productivity contributes to the connection between patents and technology innovation.

In this manner, PISA may be said to be a determiner for patent production, one of the most important indicator for competitive economies as well as enabling to assess students' academic knowledge. But there are so many critics about its inefficiency in determining creativity for patent production and competitive environment while PISA enables just to assess students' cognitive skills (Deng \& Gopinathan, 2016; Sjoberg, 2016; Zhao, 2016). It has been seen that especially USA's higher success in patent production is not parallel with its average scores and rankings in PISA 2012 mathematical, science and reading literacy. USA is an exception. It has been stated that there are many negative results about PISA 2012 in the critical letter that has been published by academics and educationalists worldwide. So, those negative results are that PISA results assess students especially with quantitative data, and accordingly it couldn't assess them in terms of quality defined in the educational politics, and PISA is 
about assessable aspect of education and it couldn't evaluate students' long term skills like creativity and entrepreneurship (Academics Letter, 2014). Therefore, it may be said that PISA is adequate for evaluating students' academic knowledge but it is not an evaluator for the factors enabling to growing and improving such as entrepreneurship, innovation or creativity. So, the results of the study have showed that there is no significant relationship between patent production and PISA success but its results could be used for the identifier for different categories eg. literacy or knowledge production.

According to the study results, it should be suggested that patent activities and economic development of the OECD countries and other countries from 2012 to now would be analyzed comparatively. Moreover, the relationship between research and development activities and patent applications should be suggested to be analyzed. This study analyzed 2012 patent applications of many countries in terms of different variables, and so for future studies it should be suggested that PISA 2015 and 2018 results could be analyzed comparatively for patent applications and gross national product for developed and developing countries.

\section{REFERENCES}

Academics Letter, (2014, 6th May). OECD and PISA tests are damaging education worldwide academic. The Guardian. Retrieved 29 March, 2016 from http://www.theguardian.com/education/2014/may/06/oecdpisa-tests-damagingeducation-academics..

Al, U. \& Taşkın, Z. (2015). Relationship between economic development and intellectual production. Collnet Journal of Scientometrics and Information Management, 9/1, 25-35. DOI: 10.1080/09737766.2015.1027102

Autant-Bernard, C., Chalaye, S., Gagliardini, E. \& Usai, S. (2017). European knowledge neighbourhood: Knowledge production in EU neighbouring countries and intenstity of the relationship with EU countries. Tijdschrift voor Economics en Sociale Geografie, $108 / 1,52-75$.

Başkaya, S., Klumpp, M., \& Cuypers, M. (2015). European patent registrationsmeasuring research efficency in higher education. In M. Klumpp, S. Zelewski and N. Akca (Eds.), International Perspectives on University Efficiency (pp. 203-215). Berlin: Logos Verlag Berlin GmbH.

Bjornskov, C. \& Meon, P. G. (2013). Is truth the missing root of institutions, education, and development? Public Choice, 157/3, 641-669.

Byun, J., Sung, T.E. \& Park, H.W. (2017). Technological innovation strategy: how do technology life cycles change by technological data. Technology Analysis \& Strategic Management, 30/1, 98-112.

Dang, J. \& Motohashi, K. (2015). Patent statistics: A good indicator for innovation in China? Patent subsidy program impacts on patent quality. China Economic Review, 35: 137-155. 
Deng, Z. \& Gopinathan, S. (2016). PISA and high performing education systems: explaining Singapore's education success. Comparative Education, 52/4, 449-472. DOI: $10.1080 / 03050068.2016 .1219535$.

Drivas, K., Economiodu, C. \& Tsionas, E. G. (2018). Production of output and ideas: Efficiency and growth patterns in the United States. Regional Studies, 52/1, 105-118.

Federico, A. \& De La Vega, R. (2010). Knowledge management and innovation: What must governments do to increase innovation? In A. Green, M. Stankosky and L. Vandergriff (Eds.), In Search of Knowledge Management (pp.275-287). United Kingdom: Emerald Group Publishing Limited.

Florida, R. \& Mellander, C. (2010). Skill and cross-national economic performance. The Royal Institute of Technology Centre of Excellence for Science and Innovation Studies (CESIS), Electronic Working Paper Series paper no. 220. Retrieved 29 March, 2016 from https://www.researchgate.net/profile/Charlotta_Mellander/publication/46470129_Skill_ and_Cross-National_Economic_Performance/links/5437a01f0cf2d5fa292b48a7.pdf.

Furuoka, F. (2018). Is population beneficial to economic growth? An empirical study of China. Qual Quant, 52: 209-225. Retrieved 29 January, 2018 from https://doi.org/10.1007/s11135-016-0463-6.

Garza-Rodriguez, J., Andrade-Velasco, C.I., Martinez-Silva, K.D., Renteria-Rodriguez, F.D., \& Vallejo-Castillo, P.A. (2016). The relationship between population growth and economic growth in Mexico. Econ. Bull. 36: 97-107.

Gneezy, U., List, J. A., Livingston, J.A., Sadoff, S., Qin, X. \& Xu, Y.(2017). Measuring success in education: The role of effort on the test itself. Retrieved 27 February, 2018 from http://www.nber.org/papers/w24004.pdf.

Henri, D., Damayanty, M. S., Jacky, K., \& Jean-Marie Jr, D. (2015). Automatic patent analysis used to improve innovation and development in developing countries. British Journal of Applied Science and Technology, 7/3, 237-252.

Hoareau, C., Ritzen, J., \& Marconi, G. (2013). Higher education and economic innovation, a comparison of European countries. IZA Journal of European Labor Studies, 2/24, 1-24.

Hu, A.G.Z., Zhang, P. \& Zhao, L. (2017). China as number one? Evidence from China's most recent patenting surge. Journal of Development Economics, 124: 107-119.

Hudson, J., \& Minea, M. (2013). Innovation, intellectual property rights, and economic development: a unified empirical investigation. World Development, 46, 66-78.

Kalanje, M. C. (2017). Role of intellectual property in innovation and new product development. Retrieved $23^{\text {rd }}$ April, 2017 from http://www.wipo.int/sme/en/documents/ip_innovation_development_fulltext.html. 
Kavak, Ç. (Şubat, 2009). Bilgi ekonomisinde inovasyon kavramı ve temel göstergeleri. The paper presented in XI. Akademik Bilişim Conference, Harran University, Şanlıurfa.

Khramova, E., Meissner, D. \& Sagieva, G. (2013). Statistical patent analysis indicators as a means of determining country technology specialization. Retrieved 23rd April, 2017 from https://www.hse.ru/data/2013/04/10/1297571825/09STI2013.pdf.

Kourtit, K., Nijkamp, P. \& Stough, R. R. (2018). Modeling regional growth and innovation. International Regional Science Review, 41/1, 3-6. DOI: $10.1177 / 0160017617698743$.

Merriam, S. B., \& Tisdell, E. J. (2016). Qualitative research: A guide to design and implementation. (4th edition). San Francisco: Jossey- Bass Publication.

Parcero, O. J., \& Ryan, J. C. (2016). Becoming a knowledge economy: The case of Qatar, UAE, and 17 benchmark countries. Journal of Knowledge Economy, 1-28. DOI:10.1007/s13132-016-0355-y.

Picci, L. \& Savorelli, L. (2018). The inventor balance and the functional specialization in global inventive activities. Economics of Innovation and New Technology, 27/1, 3961. DOI: $10.1080 / 10438599.2017 .1293598$.

Pradhan, R. P., Arvin, M. B. \& Bahmani, S. (2018). Are innovation and financial development causative factors in economic growth? Evidence from a panel granger causality test. Technological Forecasting \& Social Change, https://doi.org/10.1016/j.techfore.2018.01.024.

Punch, K. F. (2014). Sosyal araştırmalara giriş: Nicel ve nitel yaklaşımlar. (Çev. Bayrak, D., Arslan, H. B. and Akyüz, Z.). Ankara: Siyasal Kitabevi. Rowlinson, M. (2004). Historical analysis of company documents. In C. Cassell and G. Symon (Eds.), Essential Guide to Qualitative Methods in Organizational Research (pp. 301-312). London: Sage Publications.

Raghupathi, V. \& Raghupathi, W. (2017). Innovation at country-level:association between economic development and patents. Journal of Innovation and Entrepreneurship, 6/4, 1-20. Doi: 10.1186/s13731-017-0065-

Robinson, D. \& Raven, M. (2017) 1dentifying and preventing biopiracy in Australia: Patent landscapes and legal geographies for plants with indigenous Australian uses. Australian Geographer, 48/3, 311-331.

Sims, P.C. (2013). PISA and labor productivity: Is PISA an accurate measure of the future economic capacity of students? Unpublished master thesis. Graduate School of Arts and Sciences of Georgetown University, Washington D.C. Retrieved $23^{\text {rd }}$ April, 2017 from

https://repository.library.georgetown.edu/bitstream/handle/10822/558579/Sims_georget own_0076M_12128.pdf? sequence=1\&isAllowed=y. 
Sjoberg, S. (2016). OECD, PISA, and Globalization: The influence of the international assessment regime. In C. H. Tienken and C. A. Mullen (Eds.), Education Policy Perils, Tackling the tough issue (pp.102-133). UK: Routledge Publications.

Srivastava, A. K. (2017). Innovative knowledge and command on intellectual fruits: A jurisprudence of court in conflict on pharmaceutical patent. Imperial Journal of Interdisciplinary Research, 3/5, 71-74.

Tan, J.P., Calleon, I., Ng H. L., Poon C. L. \& Koh, E. (2018). Collective creativity competencies and collaraborative problem-solving outcomes: insights from the dialogic interactions of Singapore student teams. In Care E., Griffin P., Wilson M. (eds) Assessment and Teaching of $21^{\text {st }}$ Century Skills. Educational Assessment an Information Age. Springer Publishing, Cham.

Tebaldi, E. \& Elmslie, B. (2013). Does institutional quality impact innovation? Evidence from cross-country grant data. Applied Economics, 45/7, 887-900. DOI: $10.1080 / 00036846.2011 .613777$

TMMOB. (2007). Ülke örnekleri ile kalkınma ve sanayileşme modelleri. TMMOB Sanayi Kongresi 2007 Oda Raporu. Retrieved 28 March, 2016 from http://www.mmo.org.tr/resimler/dosya_ekler/403675579f61145_ek.pdf.

Wen, J., Yang, X. Y., Feng, G.F., Sui, B. \& Chang, C. P. (2017). Qual Quant, 51: 24892506. DOI: $10.1007 / \mathrm{s} 11135-016-0405-3$.

Woo, S. \& Choi, J. Y. (2018). Knowledge sources and recombination capabilities in developing new convergent products. Technology Analysis \& Strategic Management, $30 / 2,227-240$.

World Intellectual Property Organization (WIPO). (2013). World Intellectual Property

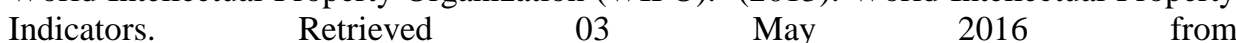
http://www.wipo.int/edocs/pubdocs/en/intproperty/941/wipo_pub_941_2013.pdf.

Yin, R. K. (2014). Case study research: Design and methods. (5th edition). United State of America: SAGE Publications.

Yoon, J., Oh, Y. \& Lee, J.D. (2017). The impact of policy consistency on technological compettiveness: A study on OECD countries. Energy Policy, 108: 425-434.

Zahringer, K., Kolympiris, C. \& Kalaitzandonakes, N. (2017). Academic knowledge quality differentials and the quality of firm innovation. Industrial and Corporate Change, 26/5, 821-844. DOI: 10.1093/icc/dtw050.

Zhang, S. (2015). Analysis of the correlation between population growth and economic development in Asian countries. Cross Cult. Commun. 11: 1-6. 
Zhao, Y. (2016). Who is afraid of PISA: The fallacy of international assessments of system performance? In A. Harris and M. S. Jones (Eds.), Leading Futures Global Perspectives on Educational Leadership (pp.7-22). New Delhi: SAGE Publications. 